\title{
DE SPANWIJDTE VAN DE LEIDING EN HET AANTAL NIVEAUX VAN LEIDING
}

\author{
door N. C. Looijaard
}

1. Onder bovenstaande titel was een stuk gereed om uitgetypt te worden, toen ik het Januari-nummer van 1955 van dit blad ontving, waarin $D_{r}$ A. de Jong een artikel 1) publiceerde, dat op vele punten parallel loopt met wat ik geschreven had. Waar ik echter enige problemen op andere wijze benaderd heb en bovendien op sommige punten van diens betoog critiek heb, meende ik het onderstaande toch nog onder de aandacht van de lezers te mogen brengen.

2. Op pag. 6 e.v. werkt de Jong het z.g. theorema van Graicunas 2 ) uit. Deze ziet drie soorten contacten tussen de personen, die een organisatie vormen, n.l.:

a. directe contacten;

b. groeps-contacten;

c. kruiselingse contacten

en stelt het totaal van deze contacten als bepalend voor de hoeveelheid werk, welke een superieur te verrichten heeft. In tegenstelling tot de Jong, die dit van Graicunas overneemt, meen ik te mogen stellen, dat een superieur met de kruiselingse contacten alleen te maken heeft via de groepscontacten en heb ik in mijn berekening alleen gebruik gemaakt van de contacten a en b. Het verloop van de curve, welke wordt voorgesteld door de formule $\mathrm{C}=$ $f(A)$ wordt dan iets minder steil (en ligt meer naar rechts), hetgeen volgt uit het feit dat de eerste afgeleide uit deze functie voor de verschillende waarden van A (dit is de spanwijdte van de leiding, welke de Jong vanaf $\S 4$, , ${ }^{\prime \prime}$ noemt) lager wordt.

Een tweede bezwaar tegen de redenering van schrijver is zijn verklaring dat, aangezien de helling van de functie voor $A=5$ aanzienlijk groter is dan die voor $A=4$, de spanwijdte dus 4 is. Ik kan echter met hetzelfde recht zeggen dat, aangezien de helling voor $A=6$ groter is dan voor $A=5$, de spanwijdte dus 5 moet zijn.

Verder meent schrijver uit het voorgaande te mogen concluderen .,dat het aantal door éen superieur te leiden ondergeschikten gelijk is aan 4." (cursivering van de J.) (pag. 8). Dit is onjuist, aangezien het mogelijke aantal contacten van een leider slechts één der vele bepalende factoren is voor de spanwijdte der leiding ${ }^{3}$ ). Met name is hier de menselijke factor buiten beschouwing gelaten, welk bezwaar trouwens aan het gehele artikel

1) Dr A. de Jong, Enige opmerkingen over het verschijnsel van de spanwijdte van de leiding als grondslag voor een algemene theorie van organisatie en leiding der bedrijfshuishouding. M.A.B. Januari 1955 pag. 4/17.

2) V. A. Graicunas, Gestaltung der Beziehungen im Betriebe.

Mitteilungen des internationalen Rationalisierungs Institutes, Marz 1933 s. 41/4.

3) Dr John M. Pfiffner schrijft in zijn artikel "The .,Third Dimension" of Organization". Personell, Maart 1952 pag. 393 onder verwijzing naar Norman F. R. Maier, Psychology in Industry, Houghton Mifflin Co Boston 1946 pag. 108/29: „The fact of individual differences is well established psychologically. This being so, it would seem to follow that no absolute span of supervision can be established (cursivering van mij N.L.) to apply to all individuals. The most that can be hoped for is probably an optimum range." En iets verder: "Attempts should also be made to discover variations associated with hierarchical level." 
van de Jong kleeft. Zijn uitspraken zijn absoluut, waar ze in feite slechts een heel voorzichtige benadering kunnen zijn.

3. Door mij is het probleem op de volgende wijze benaderd. Ik veronderstel dat op het laagste niveau van leiding de spanwijdte 15 is (ik kom daarop hierna terug) bij een aantal arbeiders $(A)$ van 7500 . Noemen we het aantal leiders op het laagste niveau van leiding $A^{\prime}$, de spanwijdte $S$, het aantal niveaux hierboven $\mathrm{N}^{\prime}$ en het aantal leiders hierboven $\mathrm{L}$, terwijl eenhoofdige topleiding wordt aangenomen, dan kan aan de hand van de formule

$$
\mathrm{L}=\frac{\mathrm{S}^{\mathrm{N}^{\prime}}-1}{\mathrm{~S}-1}
$$

waarin $\mathrm{S}^{\mathrm{N}^{\prime}}\left(\sqsubseteq \mathrm{A}^{\prime}\right)$ een constante is, de relatie tussen de opeenvolgende waarden van $S$ en $N^{\prime}$ worden berekend $\left(N^{\prime} \log S=\log A^{\prime}\right)$.

Deze relatie is grafisch voorgesteld in Fig. 1.

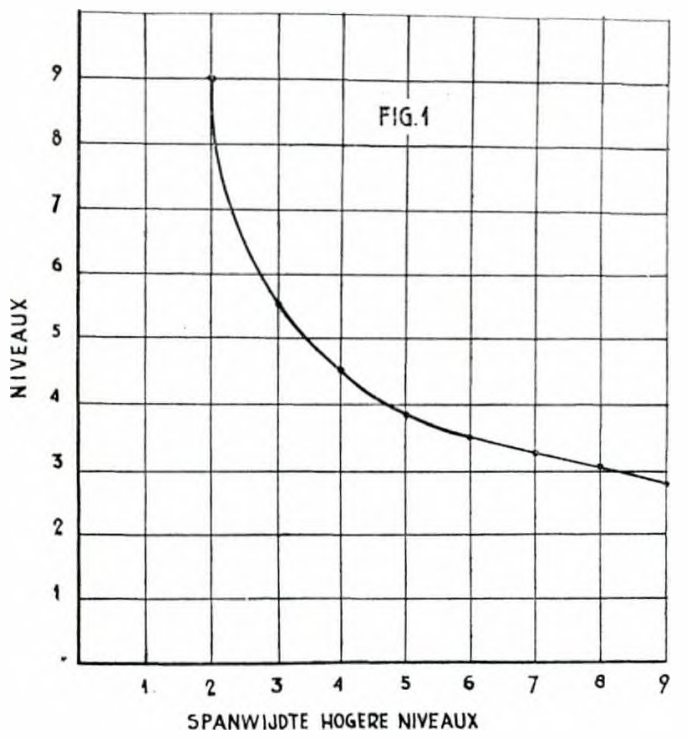

Hieruit blijkt, dat bij een spanwijdte $<5$ het aantal niveaux van leiding onevenredig sterk toeneemt, terwijl bij een spanwijdte $>8$ vrijwel geen vermindering van het aantal niveaux verkregen kan worden. We kunnen hieruit dus concluderen, dat de optimale spanwijdte op de hogere niveaux van leiding zal variëren van 5 tot 8 .

4. Zoals de Jong (pag. 9) ook opmerkt, zal de spanwijdte afnemen naarmate men op hoger niveau komt. Maar (wil ik er aan toevoegen) ook toenemen naar beneden toe.

De grenzen van de spanwijdte op het laagste niveau kunnen op soortgelijke wijze als hiervóór de spanwijdte op de hogere niveaux, benaderd worden.

Veronderstellen we een aantal arbeiders van 10.000 en een spanwijdte van de hogere niveaux van 5, dan geeft onderstaande grafiek (Fig. 2) de aantallen leiders voor achtereenvolgende waarden van de spanwijdte op het laagste niveau van leiding. 


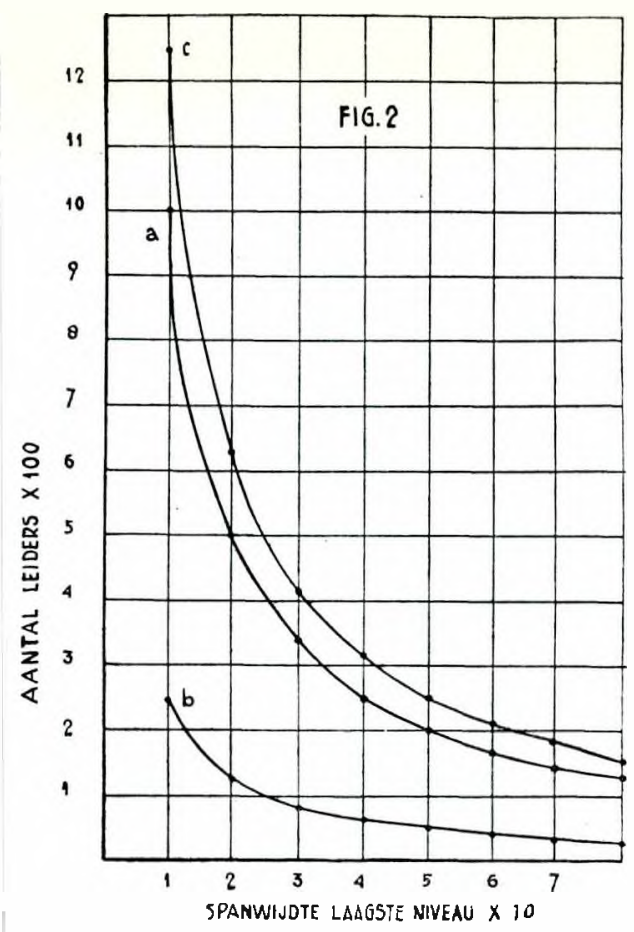

curve $\mathrm{a}=$ aantal leiders op het laagste niveau van leiding; curve $b=$ aantal leiders op de hogere niveaux;

curve $\mathrm{c}=\mathrm{a}+\mathrm{b}$

Hieruit blijkt, dat bij een spanwijdte $<30$ het aantal leiders in zeer snel tempo stijgt en bij een spanwijdte $>40$ de relatieve daling van het aantal leiders vrij gering is. De conclusie zou dus moeten luiden, dat de optimale spanwijdte van de leiding op het laagste niveau tussen 30 en 40 moet liggen.

Het feit, dat de praktijk in het algemeen dit aantal te hoog acht, stelt duidelijk in het licht, hoe voorzichtig men in de organisatieleer moet zijn met conclusies, die alleen gebaseerd zijn op cijfers ${ }^{4}$ ).

Dat de spanwijdte op het laagste niveau van leiding echter belangrijk hoger kan zijn dan 5 a 8 , kan op eenvoudige wijze beredeneerd worden. Op het niveau van uitvoering zijn de kruiselingse contacten en daardoor de groepscontacten van de leider, veel geringer dan op de hogere niveaux en deze contacten zijn geringer, naarmate het werk, dat in een groep (onder één leider) verricht wordt, eenvormiger is. Dit stemt overeen met het ervaringsfeit, dat een chef meer personeel kan leiden, naarmate de werkzaamheden van zijn ondergeschikten meer van gelijke aard zijn.

We hebben dus gezien dat, indien we alleen gebruik maken van quantificeerbare gegevens, de grenzen van de spanwijdte op het laagste leidersniveau liggen tussen enerzijds 5 en 8 en anderzijds 30 en 40. Deze waarden liggen relatief zo ver uiteen, dat ze weinig praktische waarde hebben.

5. In $\S 3$ stelt schrijver dat ,, op hoger niveau ongetwijfeld de spanwijdte van de leider kleiner (zal) zijn" (pag. 9), hetgeen in $\$ 8$ herhaald wordt. $\mathrm{Na}$ de gegeven berekening volgt dan: ,Aangezien $\mathrm{r}>1$ (voortvloeiend uit de vooronderstelling, dat de spanwijdte kleiner wordt N.L.), zal de hyper-

4) Het is anderzijds wel interessant te lezen, dat The International Business Machines Corporation bij haar reorganisatie in het begin der veertiger jaren, de spanwijdte op het laagste niveau van leiding terug bracht van 48 op 36. 
bool, welke de functie (12) uitbeeldt, rechts liggen van die welke (5) uitbeeldt. Dit betekent dus dat het raakpunt der kostenlijn eveneens naar rechts verschuift. Met andere woorden de kosten aan de leiding van arbeiders verbonden zullen door het loslaten van onze veronderstelling (gelijke spanwijdte op alle niveaux N.L.) groter worden." (pag. 16).

In normaal Nederlands vertaald (ik bedoel hier niets discriminerends mee) betekent dit, dat de kosten het laagst zijn, wanneer de spanwijdte van de leiding op alle niveaux gelijk is, en dat een wijziging van de spanwijdte op sommige niveaux (waardoor dan de spanwijdte op verschillende niveaux ongelijk wordt) altijd kostenverhogend zou werken.

Deze foutieve conclusie spruit voort uit het feit, dat de Jong alleen kijkt naar het kleiner worden van de spanwijdte, naarmate het niveau hoger wordt en verzuimt het feit in beschouwing te nemen, dat naar beneden toe de spanwijdte groter zal worden.

Stellen we $\mathrm{r}<1$, dan is de tendens juist andersom en luidt de conclusie, dat de kosten van leiding lager worden.

Ook zonder deze berekeningen is het duidelijk dat, ceteris paribus (welke veronderstelling schrijver ook stilzwijgend maakt), de kosten van leiding lager moeten worden bij vergroting van de spanwijdte en hoger bij verkleining ervan.

Uiteraard zoekt men op ieder niveau de optimale spanwijdte en geen enkele theorie kan aantonen dat het optimum bereikt kan worden alleen, wanneer de spanwijdte overal even groot is.

6. In $\S 6$ wordt de vergroting van $S$ verondersteld gepaard te gaan met een toename van $K(=$ kosten van de leiding) met een constante $c(c>1)$. Het gebruik van deze constante wordt behandeld sub 7 .

$\mathrm{Er}$ is bovendien een praktisch bezwaar. Deze kosten zijn $\mathrm{nl}$. in de praktijk maar voor een deel te berekenen en voor het overige zelfs niet te benaderen. De vergroting van S (= spanwijdte) zal n.l. dikwijls gepaard gaan met het afsplitsen van de constituerende arbeid van de leiding (functionalisatie). De berekening der hieraan verbonden kosten behoeft geen overwegende moeilijkheden op te leveren.

Een voortgaande toename (resp. afname) van $\mathrm{S}$ zal echter tevens afnemende (resp. toenemende) efficiëncy in het bedrijf veroorzaken en hoewel deze veranderde efficiëncy belangrijk kan zijn, zal het uitdrukken hiervan in een getal niet tot de mogelijkheden behoren.

Vergelijking van de efficiëncy voor en na de wijziging is misschien nog mogelijk. Het bepalen van het deel der verandering in de efficiëncy, dat aan de wijziging van $S$ is toe te schrijven, moet echter een slag in de lucht blijven. Hiermede komt de praktische bruikbaarheid van de grafieken in $\S 6$ in een geheel ander licht te staan.

7. Tenslotte stelt schrijver op pag. 16, dat de gedaante van de functie $\mathrm{S}=\mathrm{f}(\mathrm{h})$ (waarbij $\mathrm{h}$ de hoogte van het leidende niveau voorstelt) van die aard is, dat bij toename van $\mathrm{h}$, S kleiner wordt, waarmede bedoeld wordt. dat de spanwijdte kleiner wordt naarmate men op een hoger niveau komt.

$\mathrm{H}_{\mathrm{ij}}$ geeft daarbij de functie de vorm

$$
\mathrm{S}=\mathrm{q}-\mathrm{ah}
$$

waarin $q$ en $h$ constanten zijn (cursivering van mij N.L.).

Dit impliceert echter, dat de afname van de spanwijdte naar boven (resp. de toename naar beneden) een regelmatig verloop heeft, hetgeen niet overeenstemt met hetgeen de praktijk te zien geeft. 
Uitgaande van $q$ en a als constanten, introduceert de Jong de factor ,r" als constante in de formule

$$
\mathrm{Fx}=\mathrm{F} \times \mathrm{r}(\mathrm{r}>1)
$$

en door substitutie

$$
F_{x}=\frac{A-1}{S-1} r
$$

waaruit de conclusie wordt getrokken, dat (12) grafisch kan worden voorgesteld door een hyperbool. Maar hoe zou de voorstelling worden, wanneer het verschil tussen de spanwijdten der opeenvolgende niveaux van leiding geen constante is?

8. Ik ben in mijn critiek hier en daar wat scherp geweest. Ik hoop dat mijn belangstelling voor dit onderwerp Dr. de Jong de overtuiging kan schenken, dat mijn critiek opbouwend bedoeld is. Zijn wederwwoord zie ik met belangstelling tegemoet. Immers: du choc des opinions jaillit la vérité. 